\title{
The potentiality of toxic metals to wheat crop as affected by municipal solid waste: An implication to human health
}

\author{
Zafar Iqbal Khan ${ }^{1 *}$, Kafeel Ahmad ${ }^{1}$, Fazeela Zameer ${ }^{1}$, Naunain \\ Mehmood $^{2}$, Kinza Wajid ${ }^{1}$, Aima Iram Batool ${ }^{2}$, Muhammad Nadeem ${ }^{3}$, \\ Pervaiz Akhter ${ }^{1}$, Maria Ghazzal ${ }^{1}$, Mubeen Akhtar ${ }^{1}$, Humayun Bashir ${ }^{1}$, \\ Asma Ashfaq ${ }^{1}$, Mudasra Mnuir ${ }^{1}$ and Ifra Saleem Malik ${ }^{1}$ \\ 1. Department of Botany, University of Sargodha, Sargodha-Pakistan \\ 2. Department of Zoology, University of Sargodha, Sargodha-Pakistan \\ 3. Institute of Food Science and Nutrition, University of Sargodha, Sargodha-Pakistan \\ *Corresponding author's email: zafar.khan@uos.edu.pk \\ Citation \\ Zafar Iqbal Khan, Kafeel Ahmad, Fazeela Zameer, Naunain Mehmood, Kinza Wajid, Aima Iram Batool, \\ Muhammad Nadeem, Pervaiz Akhter, Maria Ghazzal, Mubeen Akhtar, Humayun Bashir, Asma Ashfaq, \\ Mudasra Mnuir and Ifra Saleem Malik. The potentiality of toxic metals to wheat crop as affected by municipal \\ solid waste: An implication to human health. Pure and Applied Biology. Vol. 9, Issue 1, pp809-820. \\ http://dx.doi.org/10.19045/bspab.2020.90087
}

\begin{tabular}{llll}
\hline \hline Received: 07/09/2019 & Revised: 01/12/2019 & Accepted: 13/12/2019 & Online First: 01/01/2020 \\
\hline
\end{tabular}

\section{Abstract}

The by-product of industrial and municipal wastewater is sewage sludge. It is enriched with a lot of organic nutrients. The sewage sludge that has high amount of organic matter, micronutrients, and macro-nutrients, are usually used as fertilizer for horticultural crops. The impact of sewage sludge on heavy metal's uptake ratio by wheat variety is observed by conducting a pot experiment. The amount of heavy metals in various parts of wheat plant was analyzed by atomic absorption spectrophotometer (AA-6300 Shimadzu Japan). The metals concentration in grains of wheat ranged from 0.64 to 0.97 for $\mathrm{Zn}, 0.76$ to 0.93 for $\mathrm{Co}, 1.30$ to 1.61 for $\mathrm{Cd}$ and 0.81 to $1.58 \mathrm{mg} / \mathrm{kg}$ for Fe, respectively. All metal concentrations were found below the permissible limits suggested by FAO/WHO. The calculation for translocation and bio-concentration factor for various parts of the wheat crop was done. However, there may be a risk of the presence of potentially unsafe substances in the sewage sludge e.g., pathogens and heavy metals.

Keywords: Contamination; Health risk; Metal; Sewage sludge; Triticum aestivum

\section{Introduction}

Sewage sludge is considered as a good biological resource for recycling the nutrients when it is applied in the agricultural land. Thus, sewage sludge has an important role in sustainable agriculture. Sewage sludge gives a better plant yield when it is used in agricultural land as an organic fertilizer. When sewage sludge was used as organic fertiliser, it produces a good plant yield [1-3].
For burgeoning population wheat (Triticum aestivum L.) is considered as a potential food source. Every year, wheat is grown in millions of tons [4]. In Pakistan, wheat has central position in cereals, and it has a $66 \%$ annual food crop area, it also provides average diet calories about $60 \%$ [5]. Different factors effects on wheat, such as heavy metals, infertile soil, drought, waterlogging, and salinity. As a 
result of these factors wheat yields becomes low $[6,7]$.

In the food chain, the role of heavy metal is focused by the sewage sludge research application. Microbial activity in soil increased due to sewage sludge application at recommended rates and tied up to the unavailability of the heavy metals to the plant and soil $[8,9]$.

The sewage sludge use in bio-solids form is considered as the pervasiveness of microorganisms and it is another factor which needs careful attention. The biosolids sewage sludge contains viruses, pathogenic bacteria, protozoa, and parasitic helminths, etc. These pathogens cause potential health hazards to human, plants, and animals. Microbes cause health risk when sewage sludge applied to land. Among identified microbes Taenia and Salmonella were the greatest concern. By appropriate sludge treatment, there would be a maximum reduction in several parasitic and pathogenic organisms prior to its application into land. Furthermore, after its application, health hazards become reduced because of some factors like climate, time and soil microorganisms [10].

The development and growth of plants may be inhibited by those heavy metals which easily assimilated by plants at high concentrations. Moreover, metals cause damage to cell membranes in plants, metals decreases the transpiration rate, damaging the photosynthetic organelles, increasing the lipid peroxidation, and destroying protein synthesis. Most of the metals including $\mathrm{Ni}, \mathrm{Cr}, \mathrm{Cd}, \mathrm{Cu}, \mathrm{Pb}, \mathrm{Zn}$ are potentially called toxic elements that originate in sewage. The association of these metals with settable solids is concentrated in sludge in the course of primary treatment as well as secondary treatment processes [11].

The food chain is affected by heavy metals acquisition in plants and threatens the health of humans. Environmental stress is very effective on plant protection mechanisms, as plants have ability to accumulate the proline [12].

Heavy metals have a high environmental concern, harmful to animals, humans and also susceptible to food chain. In urban areas heavy metals come from different sources. In topsoil's heavy metals contamination arises due to atmospheric pollution [13-15].

The present research was performed with objectives: (1) to examine the impact of sewage sludge on uptake of metal by different portions of wheat plant, (2) to determine transfer factor and factor of bioconcentration, (3) to appraise pollution severity of soil, (4) to estimate health risk index.

\section{Materials and Methods Experimental design}

In Botany Department's ground, a pot experiment was conducted in University of Sargodha from Sargodha during the year 2016-2017. The soil used in the present study was collected from ponds and ditches located in nearby areas of Sargodha. Took 12 pots and filled with soil. After that, wheat variety (Aas) seeds were sown in four cultivation groups with the amendment rates of sewage sludge: T-I consisted of $100 \%$ ground soil, T-II consisted of $75 \%$ ground soil and $25 \%$ sludge of sewage, T-III $50 \%$ ground soil and $50 \%$ sludge of sewage, T-IV consisted of $25 \%$ ground soil and $75 \%$ sludge of sewage.

Filling of each pot with respective treatment in $3 \mathrm{~kg}$ was done. After filling pots were placed as randomized complete block (RCB) design and three replications per treatment was made. Then by using groundwater, all the pots were irrigated. Irrigation was done two times in a week and in each pot 12 seeds were sown. Twelve seeds were hand sown on November 2016 in each pot. After that Seed germination data was noted and finally for complete plant growth, five plants were contained in every pot. Maturation period was five months.

\section{Sample collection and preparation}


In April 2017, harvesting was done. From each pot, all samples were collected after harvesting, and then for two days the drying of plant material was carried out at $70{ }^{\circ} \mathrm{C}$, was weighed and ground into a fine powder.

\section{Sample digestion}

Samples digestion was brought about in a 3: $1 \mathrm{HNO}_{3}$ mixture: $\mathrm{H}_{2} \mathrm{O}_{2}$ by the wet digestion method. All the samples were kept in a measuring flask up to $50 \mathrm{ml}$ as final volume. The samples filtration was then carried out by Whatman filter paper No. 42. The samples of soil were assembled from the upper 3-5 cm layer of the soil from every pot. After air drying, samples of soil were placed in the oven for two days at $65{ }^{\circ} \mathrm{C}$. The samples were digested in the same manner.

\section{Heavy metal analysis}

Atomic absorption spectrophotometer (AA-6300 Shimadzu Japan) was used for the analysis of metals. $\mathrm{Zn}, \mathrm{Co}, \mathrm{Fe}$, and $\mathrm{Cd}$ concentration had been determined by atomic absorption spectrophotometer respectively.

\section{Quality control}

To assess the reliability and assurance of the data, such measures were taken. By comparing with the international standards, the precision of the results can be done. The repeated analyses of the examined samples can also verify the accuracy of the analyses.

\section{Data analysis}

Data analysis was done through SPSS (ver. 14.0, SPSS Inc., Chicago, IL) and firstly, one-way analysis of variance (ANOVA) was used for data analysis. Then R-value (coefficient of correlation) and mean standard deviation of crop and soil parameters having concentrations of sludge were calculated by using MS Excel (ver. 2003, Microsoft Redmond Campus, Redmond, WA) and finally graphs were made through Sigma Plot (ver. 12.3, Systat Software, Inc., Chicago, IL).

For heavy metals accumulation from the soil, a bioaccumulation (BAF) factor was measured in to check the plants' efficiency [16]:

$\mathrm{BAF}=$ Concentration of metal in roots $(\mathrm{mg} / \mathrm{kg}) /$ Concentration of metal in soil $(\mathrm{mg} / \mathrm{kg})$

For translocation of heavy metal from roots towards the shoot of plant, a translocation factor (TF) found out to check the capability of plants.

$\mathrm{TF}=$ Concentration of metal in shoots $(\mathrm{mg} / \mathrm{kg}) /$ Concentration of metal in roots $(\mathrm{mg} / \mathrm{kg})$

Pollution load index (PLI) of every treatment was calculated [17].

PLI $=$ Determined level of metal in the soil being investigated/reference value of soil metals

Daily intake of metal (DIM) was computed according to Sajjad et al. [18].

$\mathrm{DIM}=\mathrm{D}_{\text {food intake }} \times \mathrm{C}_{\text {metal }} / \mathrm{B}_{\text {average weight }}$

Where: $\mathrm{C}_{\text {metal }}, \mathrm{B}_{\text {average weight, and }} \mathrm{D}_{\text {food intake }}$ refer to concentrations of heavy metal $(\mathrm{mg} / \mathrm{kg})$ in food crop, average body weight (kg) and daily intake of a food crop (kg/day) respectively.

Body's average weight was taken as 55.9 $\mathrm{kg}$ and metal's daily intake in wheat as $0.318 \mathrm{~kg} /$ day per person respectively.

According to Cui et al. [19], health risk index (HRI) was described in terms of estimated exposure relation to metal by oral reference dose and food crop.

HRI $($ Health risk index $)=\mathrm{DIM} / \mathrm{R}_{\mathrm{f}} \mathrm{D}[20]$

Oral reference dose $\left(\mathrm{R}_{\mathrm{f}} \mathrm{D}\right)$ is the maximum acceptable oral dose of heavy metals.

As described in USEPA [20], HRI $>1$ is considered as very dangerous for humans.

For calculating soil pollution extent, enrichment factor (EF) was calculated the following and Al-Hwaiti and AlKhashman [21].

$\mathrm{EF}=$ Metal concentration examined in amended soil/ Metal's concentration in control soil.

\section{Results and discussion}

\section{Zinc concentration in the soil}

Analysis of variance of $\mathrm{Zn}$ concentration showed a significant effect $(p<0.05)$ in soil from four treatments which were employed for growing wheat variety. The 
$\mathrm{Zn}$ value detected in the soil was 2.61 to $2.74 \mathrm{mg} / \mathrm{kg}$ in the present study. The mean $\mathrm{Zn}$ concentration values were in order: $\mathrm{T}$ IV $>$ T-III $>$ T-II $>$ T-I (Table 1 ).

Ozyazici [22] obtained the highest value i.e. $83.38-58.81(\mathrm{mg} / \mathrm{kg})$ for zinc as compared to recent research values. Similarly, Yu et al. [23] founded the greater value of $\mathrm{Zn}$ than the value attained in current work. Stefanovic et al. [24] observed a higher amount of $\mathrm{Zn}$ than present, by working on different varieties of wheat. Current $\mathrm{Zn}$ values are lower than the calculations of Ran et al. [25]. Zinc is a vital micronutrient and is involved in numerous metabolic processes of plants.

Table 1. Metal's mean concentration $(\mathrm{mg} / \mathrm{kg})$ in soils, shoots, roots and grains of wheat

\begin{tabular}{|c|c|c|c|c|}
\hline Metal & T-I & T-II & T-III & T-IV \\
\hline \multicolumn{5}{|c|}{ Soil } \\
\hline $\mathrm{Zn}$ & $2.61 \pm 0.13$ & $2.64 \pm 0.14$ & $2.68 \pm 0.15$ & $2.74 \pm 0.16$ \\
\hline $\mathrm{Co}$ & $1.06 \pm 0.03$ & $1.16 \pm 0.04$ & $1.19 \pm 0.05$ & $1.22 \pm 0.06$ \\
\hline $\mathrm{Cd}$ & $3.34 \pm 0.13$ & $3.38 \pm 0.15$ & $3.46 \pm 0.17$ & $3.44 \pm 0.19$ \\
\hline $\mathrm{Fe}$ & $32.72 \pm 1.92$ & $39.07 \pm 1.99$ & $44.23 \pm 2.21$ & $44.25 \pm 2.19$ \\
\hline \multicolumn{5}{|c|}{ Root } \\
\hline $\mathrm{Zn}$ & $2.16 \pm 0.11$ & $2.19 \pm 0.13$ & $2.23 \pm 0.14$ & $2.31 \pm 0.15$ \\
\hline $\mathrm{Co}$ & $1.05 \pm 0.04$ & $1.09 \pm 0.05$ & $1.12 \pm 0.06$ & $1.21 \pm 0.07$ \\
\hline $\mathrm{Cd}$ & $2.89 \pm 0.11$ & $2.92 \pm 0.12$ & $3.11 \pm 0.19$ & $2.99 \pm 0.13$ \\
\hline $\mathrm{Fe}$ & $29.73 \pm 1.91$ & $36.07 \pm 2.04$ & $41.23 \pm 2.21$ & $41.24 \pm 2.22$ \\
\hline \multicolumn{5}{|c|}{ Shoot } \\
\hline $\mathrm{Zn}$ & $1.92 \pm 0.08$ & $1.93 \pm 0.09$ & $1.98 \pm 0.11$ & $2.05 \pm 0.12$ \\
\hline $\mathrm{Co}$ & $0.86 \pm 0.03$ & $0.97 \pm 0.04$ & $0.99 \pm 0.05$ & $1.03 \pm 0.06$ \\
\hline $\mathrm{Cd}$ & $2.64 \pm 0.11$ & $2.68 \pm 0.12$ & $2.81 \pm 0.15$ & $2.74 \pm 0.17$ \\
\hline $\mathrm{Fe}$ & $25.23 \pm 2.01$ & $31.57 \pm 2.11$ & $36.73 \pm 2.09$ & $36.75 \pm 2.08$ \\
\hline \multicolumn{5}{|c|}{ Grains } \\
\hline $\mathrm{Zn}$ & $0.64 \pm 0.09$ & $0.89 \pm 0.11$ & $0.97 \pm 0.12$ & $0.97 \pm 0.12$ \\
\hline $\mathrm{Co}$ & $0.76 \pm 0.03$ & $0.87 \pm 0.04$ & $0.89 \pm 0.05$ & $0.93 \pm 0.06$ \\
\hline $\mathrm{Cd}$ & $1.39 \pm 0.09$ & $1.61 \pm 0.13$ & $1.49 \pm 0.11$ & $1.52 \pm 0.14$ \\
\hline $\mathrm{Fe}$ & $0.81 \pm 0.28$ & $1.32 \pm 0.34$ & $1.42 \pm 0.36$ & $1.58 \pm 0.33$ \\
\hline
\end{tabular}

The concentration of zinc in wheat plant $\mathrm{Zn}$ concentration in root was observed to be between 2.16 to $2.31 \mathrm{mg} / \mathrm{kg}$ in our findings of research. The order was: $\mathrm{T}$ IV $>$ T-III $>$ T-II $>$ T-I. Zn concentration in the shoot was observed between 1.92 to $2.05 \mathrm{mg} / \mathrm{kg}$. The highest value found in $\mathrm{T}-$ IV and the lowest value found in T-I. Zinc concentration in grain varied from 0.64 to $0.97 \mathrm{mg} / \mathrm{kg}$. The $\mathrm{Zn}$ mean concentration values were in order: T-IV $=$ T-III $>$ T-II $>$ TI. The lowest value was found in T-I and the highest value was found in T-IV (Table 1).

Antolin et al. [26] stated that grain yield is increased with sewage sludge application because the amended soil's microbiological properties had improved, due to which nutrients recycling for the crop is promoted. In normal plants, the mean concentration of $\mathrm{Zn}$ in aerial tissues was $66 \mathrm{mg} / \mathrm{kg}$ [27].

\section{The concentration of cobalt in soil}

Analysis of variance showed nonsignificant effect $(p>0.05)$ on Co concentration which was taken from 4 treatments in the soil which were employed for the growth of wheat variety. The current finding of $\mathrm{Co}$ in the soil was 1.06 to $1.22 \mathrm{mg} / \mathrm{kg}$. The lowest value found in T-I and the highest value found in T-IV. The order was: T-IV $>$ T-III $>$ T-II $>$ T-I (Table 1).

Cobalt is present in the ecosystem in various forms. Ahmad et al. [28] obtained its lower value as compared to present value. In trace amount Co is essential for animals and plants but toxic at high 
concentration [29]. Cobalt toxicity depends upon nature of soil. Toxicity of Co will be greater in the presence of acidic soil [30].

\section{The concentration of cobalt in wheat plant}

The Co value in the recent study ranged between $1.05-1.21 \mathrm{mg} / \mathrm{kg}$ in the root. The mean Co concentration was found in following order: T-IV>T-II $>$ T-III $>$ T-I. The range of Co concentration in shoot was $0.86-1.03 \mathrm{mg} / \mathrm{kg}$. At T-I the mean concentration value of Co was $0.86 \mathrm{mg} / \mathrm{kg}$ and gradually increase towards T-IV. Co concentration in grain varied from 0.76$0.93 \mathrm{mg} / \mathrm{kg}$. The mean concentration values of Co were in order: T-IV $>$ T-III $>\mathrm{T}$ II $>$ T-I. The lowest value was observed in $\mathrm{T}$-I and the highest value was observed in T-IV (Table 1).

As compared to other metals Co toxicity was low. Its toxicity depends upon plant species, nature of soil and composition of the soil. Toxicity of Co affects humans through contamination of food chain [31]. It also plays important role in nitrogen fixation of leguminous plants and has detrimental effects at high concentrations in plants [32].

\section{The concentration of cadmium in soil}

Variance analysis of $\mathrm{Cd}$ concentration showed a significant effect $(p<0.05)$ in soil of four treatments which are employed for the growth of wheat variety. In this study, value of $\mathrm{Cd}$ was found to be varied from $3.34-3.44 \mathrm{mg} / \mathrm{kg}$ in the soil samples (Table $1)$.

Cadmium value attained by Ozyazici [22] was smaller as compared with the value of the present study. Less value of $\mathrm{Cd}(0.46$ $\mathrm{mg} / \mathrm{kg}$ ) was reported by $\mathrm{Yu}$ et al. [23] in distinction with existing $\mathrm{Cd}$ value. Maximum permissible value for $\mathrm{Cd}$ was 1$3 \mathrm{mg} / \mathrm{kg}$ according to EU standards reported by McGrath et al. [33]. The current value of $\mathrm{Cd}$ lies under permissible limits so it was safe. Cadmium entered in soil by the application of phosphate fertilizers, because it was added in fertilizers as impurity. Cadmium transferred quickly from root to edible parts as compared to other metals [34]. It may be hazardous for the population of microorganisms [35].

\section{The concentration of cadmium in wheat plant}

The highest value was found in T-IV. The $\mathrm{Cd}$ value showed variation in the range of 2.89 to $3.11 \mathrm{mg} / \mathrm{kg}$ in wheat root. Cadmium concentration in shoot was found in range of 2.64 to $2.81 \mathrm{mg} / \mathrm{kg}$. At $\mathrm{T}$-I the $\mathrm{Cd}$ mean concentration value was $2.64 \mathrm{mg} / \mathrm{kg}$ and highest value was 2.81 $\mathrm{mg} / \mathrm{kg}$ at T-III. Cd concentration in grain varied 1.39 to $1.61 \mathrm{mg} / \mathrm{kg}$. The mean values of $\mathrm{Cd}$ were in order: $\mathrm{T}-\mathrm{II}>\mathrm{T}-\mathrm{IV}>\mathrm{T}$ III $>$ T-I. The lowest value was observed in T-I and the highest value was observed at T-II (Table 1).

Stefanovic et al. [24] obtained the lesser value of $\mathrm{Cd}(0.01$ to $0.21 \mathrm{mg} / \mathrm{kg})$ in distinction with the present $\mathrm{Cd}$ values. The reason for high concentration of $\mathrm{Cd}$ may be the total $\mathrm{Cd}$ of soil and $\mathrm{pH}$. These two factors may be responsible for the increased concentration of $\mathrm{Cd}$ in wheat grains. Organic matter, $\mathrm{pH}$ and soil $\mathrm{Cd}$ is significantly influenced by the application of metal salts and sewage sludge [36]. Plant uptake $\mathrm{Cd}$ through their roots and accumulate it inedible parts. It accumulates in fat tissues and milk of animals [37].

\section{The concentration of iron in soil}

Analysis of variance of $\mathrm{Fe}$ concentration showed a significant effect $(p<0.05)$ in the soil of 4 treatments employed for the growth of wheat variety Aas. Iron concentration in soil varied from 32.72 to $44.25 \mathrm{mg} / \mathrm{kg}$ (Table 1).

Stefanovic et al. [24] attained the highest value of $\mathrm{Fe}$ as compared to current value when he analyzed different varieties of wheat and these values varied from 29.46$69.26 \mathrm{mg} / \mathrm{kg}$. According to FAO/WHO [38] maximum permissible level of $\mathrm{Fe}$ for crops was $425.50 \mathrm{mg} / \mathrm{kg}$ and current value lies under this safe limit. Iron in plants is slightly immobile. Iron forms stable structures and this might be the reason for high $\mathrm{Fe}$ concentration in soil in which 
wheat variety (Aas) was grown and irrigated by altered doses of domestic wastewater and groundwater.

The concentration of iron in wheat plant Analysis of variance of $\mathrm{Fe}$ concentration showed a significant effect $(p<0.05)$ in root of 4 treatments employed for the growth of wheat variety. Iron concentration in root varied from 29.73 to $41.24 \mathrm{mg} / \mathrm{kg}$. Variance analysis of $\mathrm{Fe}$ concentration showed significant effect $(p<0.05)$ in shoot from four treatments used for growing wheat variety. Iron concentration in shoot varied from 25.23 to $36.75 \mathrm{mg} / \mathrm{kg}$. Analysis of variance of $\mathrm{Fe}$ concentration showed significant effect i.e. $p<0.05$ in grain of 4 treatments employed for the growth of wheat variety. Iron concentration in grain shows variation from 0.81 to $1.58 \mathrm{mg} / \mathrm{kg}$ (Table 1 ).

Value of $\mathrm{Fe}$ obtained from present work was lesser than those found by Stefanovic et al. [24]. The high concentration of Fe was found in plants treated with sewage sludge [39]. Iron is essential for the growth of plants and animals. Many plants and animal proteins contain $\mathrm{Fe}$ that is necessary for the proper functioning of proteins and enzymes. It is confirmed from results that heavy metal concentration of soil increased with the increase in sewage sludge concentration. The high concentration of $\mathrm{Fe}$ in soil may be due to the abundance of Iron in earth crust [40].

\section{Correlation}

In $\mathrm{Fe}$ soil-root and root-shoot, the results gave positive significant correlation and shoot-grains gave positive correlation. In soil-root and root-shoot Co gave positive correlation and shoot-grain gave positive significant correlation. In $\mathrm{Cd}$ soil-root and shoot-grains demonstrated positive correlation and root-shoot demonstrated positive significant correlation. And $\mathrm{Fe}$ soil-root, root-shoot and shoot-grains in all showed positive significant correlation (Table 2).

Herren and Feller [41] and Hart et al. [42] indicated that $\mathrm{Cd}$ was accumulated in grains because it translocates by the help of vascular tissues and significant results were obtained. When $\mathrm{Cd}$ translocation occurs from stem and/or leaves to the grains, it stores in wheat grains and its current correlation values were in contrast with those obtained by Ashfaq et al. [43]. It was founded that availability of metals to plant was strongly controlled by metal's solubility in acid, chemical form and reducible form of metal [44].

Table 2. Correlation between soil-root, root-shoot and shoot-grain metal concentrations of wheat

\begin{tabular}{|c|c|c|c|}
\hline \multirow{2}{*}{ Metal } & \multicolumn{3}{|c|}{ Correlation } \\
\cline { 2 - 4 } & Soil-Root & Root-Shoot & Shoot-Grains \\
\hline $\mathrm{Zn}$ & $.997^{* *}$ & $.992^{* *}$ & .707 \\
\hline $\mathrm{Co}$ & .873 & .878 & $1.000^{* *}$ \\
\hline $\mathrm{Cd}$ & .919 & $.988^{*}$ & .195 \\
\hline $\mathrm{Fe}$ & $1.000^{* *}$ & $1.000^{* *}$ & $.961^{*}$ \\
\hline
\end{tabular}

\section{Bioconcentration factor}

At T-I the lowest value of $\mathrm{Zn}$ was 0.827 . And at T-IV the highest value of $\mathrm{Mg}$ was 0.843 . The bioconcentration factor of Co in the wheat grains varied from 0.939 to 0.9918. At T-I the BCF of Cd in the wheat grains of Aas was 0.865. At T-II the BCF of Cd was $0.863 \mathrm{mg} / \mathrm{kg}$. And T-III and TIV the values of $\mathrm{Cd}$ were 0.898 and 0.869 . The bioconcentration factor of $\mathrm{Fe}$ in the wheat grains varied from 0.908 to 0.9321 (Table 3).

Recent BCF values were higher as compared to those found by Puschenreiter et al. [45]. The higher value of $\mathrm{Cd}$ was reported in current research work than those with the results attained by Wang et al. [46]. The bioconcentration factor values for $\mathrm{Cd}$ were $>1$ as observed by Iqbal et al. [47]. According to Ran et al. 
[25], the $\mathrm{BCF}$ value for $\mathrm{Cd}$ and $\mathrm{Zn}$ was low in distinction with the present research work.

\section{Transfer factor}

The values of $\mathrm{TF}$ at all treatments were found in the following order: $\mathrm{Co}>\mathrm{Cd}>$ $\mathrm{Zn}>\mathrm{Fe}$. The TF for Co was highest while Fe was lowest among all treatments (Table 3).

All values for transfer ratios of $\mathrm{Fe}, \mathrm{Cd}$, Co and $\mathrm{Zn}$ in wheat were less than 1. For each heavy metal, both stem and leaf showed higher translocation ratio in wheat as compared to wheat grain. Furthermore, the translocation factor (TF) for leaf and stem to grain (HM grain/ HM stem and leaf) was reported to be lesser as compared to those of root to stem/leaf of wheat. The present research is in food agreement with the findings found in wheat by Bose and Battacharya [48] when the wheat was grown in soil fertilized with sewage sludge.

Table 3. Bioconcentration factor and transfer factor for all metals of wheat

\begin{tabular}{|c|c|c|c|c|}
\hline \multirow{2}{*}{ Metal } & \multicolumn{5}{|c|}{ Treatment } \\
\cline { 2 - 5 } & T-I & T-II & T-III & T-IV \\
\hline \multicolumn{5}{|c|}{ BCF } \\
\hline $\mathrm{Zn}$ & 0.8275 & 0.8295 & 0.8320 & 0.8430 \\
\hline $\mathrm{Co}$ & 0.9905 & 0.9396 & 0.9411 & 0.9918 \\
\hline $\mathrm{Cd}$ & 0.8652 & 0.8639 & 0.8988 & 0.8691 \\
\hline $\mathrm{Fe}$ & 0.9086 & 0.9232 & 0.9321 & 0.9319 \\
\hline \multicolumn{5}{|c|}{ TF } \\
\hline $\mathrm{Zn}$ & 0.2962 & 0.4063 & 0.4349 & 0.4199 \\
\hline $\mathrm{Co}$ & 0.7238 & 0.7981 & 0.7946 & 0.7685 \\
\hline $\mathrm{Cd}$ & 0.4809 & 0.5513 & 0.4791 & 0.5083 \\
\hline $\mathrm{Fe}$ & 0.0272 & 0.0365 & 0.0344 & 0.0383 \\
\hline
\end{tabular}

\section{Pollution load index}

The values of PLI at T-I, T-II, T-III and TIV were present in the following sequence: $\mathrm{Cd}>\mathrm{Fe}>\mathrm{Co}>\mathrm{Zn}$. The values of PLI for $\mathrm{Cd}$ were greatest but for $\mathrm{Zn}$ were lowest between all treatments (Table 4).

Results show that PLI value was lower for $\mathrm{Zn}$ but higher for $\mathrm{Cd}$. The pollution load index estimated how many times the concentration of metal goes beyond the background concentration and presents the toxicity level of metals in particular samples. Pollution load index values studied by Rabee [49] were reported to be varied from 0.301-0.970 and were less than one $(<1)$. He also observed that these values correspond with present values of PLI except Cd. Ahmad et al. [28] observed higher PLI values in contrast to the existing values.

\section{Enrichment factor}

The values of EF at T-I were present in the following order: $\mathrm{Cd}>\mathrm{Co}>\mathrm{Zn}>\mathrm{Fe}$, at $\mathrm{T}$-II and T-III and T-IV was: $\mathrm{Cd}>\mathrm{Zn}>\mathrm{Co}>\mathrm{Fe}$ (Table 4).

Ghrefat et al. [50] reported EF > 1 recommends that metals come from anthropogenic sources. According to the observation of McCave [51] and Horowitz and Elrick [52], EF value was high due to ionic attraction and surface adsorption. Ra et al. [53] noticed greater values of EF for $\mathrm{Co}$ and $\mathrm{Cd}$ while, lower $\mathrm{Zn}$ value in distinction with recent research.

\section{Daily intake of metals}

The daily intake of metal at T-I, T-II and T-III was observed at the order: $\mathrm{Cd}>\mathrm{Fe}>$ $\mathrm{Co}>\mathrm{Zn}$, and at $\mathrm{T}-\mathrm{IV}$ was: $\mathrm{Fe}>\mathrm{Cd}>\mathrm{Zn}>$ Co (Table 5).

Recent values of DIM were less for $\mathrm{Zn}$ and $\mathrm{Cd}$ in comparison with obtained results of Gupta et al. [54]. In humans, metal's toxicity level is dependent on its daily intake. Human health is badly affected when it is encountered with daily consumption of contaminated food. According to Sajjad et al. [18] country's 
population can be at high risk in future if DIM equal or greater than 1. For all metals, current obtained DIM values were less than 1. It was reported by Huang et al. [55] that wheat is consumed as $30 \%$ of their staple food by the people of Jiangsu province. Daily intake of metals values for rural and urban adults were $102 \mathrm{~g}$ and 62.5 $\mathrm{g}$ respectively. Values for daily intake of wheat for urban and rural children upto 6 years old were reported as $20.8 \mathrm{~g}$ and 34.1 g per day respectively.

\section{Health risk index}

Health risk index at T-I, T-II, T-III and TIV was observed in this sequence: $\mathrm{Cd}>$ $\mathrm{Co}>\mathrm{Zn}>\mathrm{Fe}$. The values of HRI were highest of $\mathrm{Cd}$ and lowest for $\mathrm{Fe}$ in all treatments (Table 5).
Result describes that HRI was lower for Fe and $\mathrm{Zn}$ but for $\mathrm{Cd}$, it was higher in all treatments. Fe and Co showed HRI values in acceptable range, while for $\mathrm{Cd}$ obtained values were not safe i.e. more than 1 . Khan et al. [56] found heavy metals having HRI values $<1$ is considered to be safe and did not hinder the food chain. Karak and Bhattacharyya [57] reported same value for $\mathrm{Zn}$ as obtained in recent research but lower value for $\mathrm{Cd}$. Value of HRI is highly dependent on the and $\mathrm{R}_{\mathrm{f}} \mathrm{D}$ and metal's daily intake. $\mathrm{R}_{\mathrm{f}} \mathrm{D}$ is the estimated value for metals per day that has no deleterious effects on human body. $\mathrm{R}_{\mathrm{f}} \mathrm{D}$ values for $\mathrm{Cd}$ and $\mathrm{Zn}$ were 0.001 and $0.30 \mathrm{mg} / \mathrm{kg}$ correspondingly [58].

Table 4. Pollution load index and enrichment factor of wheat

\begin{tabular}{|c|c|c|c|c|}
\hline \multirow{2}{*}{ Metal } & \multicolumn{5}{|c|}{ Treatment } \\
\cline { 2 - 5 } & T-I & T-II & T-III & T-IV \\
\hline \multicolumn{5}{|c|}{ PLI } \\
\hline $\mathrm{Zn}$ & 0.0590 & 0.0597 & 0.0606 & 0.0620 \\
\hline $\mathrm{Co}$ & 0.1164 & 0.1274 & 0.1307 & 0.1340 \\
\hline $\mathrm{Cd}$ & 2.2416 & 2.2684 & 2.3221 & 2.3087 \\
\hline $\mathrm{Fe}$ & 0.5750 & 0.6866 & 0.7773 & 0.7776 \\
\hline \multicolumn{5}{|c|}{ EF } \\
\hline $\mathrm{Zn}$ & 0.1090 & 0.1498 & 0.1609 & 0.1573 \\
\hline $\mathrm{Co}$ & 0.1304 & 0.1365 & 0.1361 & 0.1387 \\
\hline $\mathrm{Cd}$ & 3.1004 & 3.5486 & 3.2082 & 3.2918 \\
\hline $\mathrm{Fe}$ & 0.0033 & 0.0045 & 0.0042 & 0.0047 \\
\hline
\end{tabular}

Table 5. Daily intake of metal and health risk index via intake of wheat

\begin{tabular}{|c|c|c|c|c|}
\hline \multirow{2}{*}{ Metal } & \multicolumn{5}{|c|}{ Treatment } \\
\cline { 2 - 5 } & T-I & T-II & T-III & T-IV \\
\hline \multicolumn{5}{|c|}{ DIM } \\
\hline $\mathrm{Zn}$ & 0.0027 & 0.0038 & 0.0041 & 0.0041 \\
\hline $\mathrm{Co}$ & 0.0032 & 0.0037 & 0.0038 & 0.0040 \\
\hline $\mathrm{Cd}$ & 0.0060 & 0.0069 & 0.0064 & 0.0065 \\
\hline $\mathrm{Fe}$ & 0.0035 & 0.0057 & 0.0061 & 0.0068 \\
\hline \multicolumn{5}{|c|}{ HRI } \\
\hline $\mathrm{Zn}$ & 0.0092 & 0.0128 & 0.0139 & 0.0139 \\
\hline $\mathrm{Co}$ & 0.0765 & 0.0875 & 0.0896 & 0.0936 \\
\hline $\mathrm{Cd}$ & 6.018 & 6.97 & 6.45 & 6.58 \\
\hline $\mathrm{Fe}$ & 0.0050 & 0.0081 & 0.0087 & 0.0097 \\
\hline
\end{tabular}

\section{Conclusion}

By keeping in view the above review, it can be concluded that sewage sludge plays a significant role in sustainable agriculture when used as a soil conditioner/organic fertilizer. It increases the macro and micronutrients of the soil. It also improves its organic matter contents that result in 
improvement of soil physical condition, as well as its biological activity and health. Sewage sludge's application on wheat crop gives positive responses. Organic matter present in the sewage sludge binds the contaminants (pollutants and heavy metals) and ultimately results in a reduction of negative environmental effects of these contaminants. In wheat variety (Aas), the concentrations of $\mathrm{Co}$, $\mathrm{Cd}, \mathrm{Zn}$, and $\mathrm{Fe}$ were in the acceptable limit of standards of WHO/FAO. Consequently, this study suggests that if sewage sludge is used in smaller ratio in soil as soil conditioner/ fertilizer then there will be no major danger because of heavy metals present in the sewage sludge. Therefore, current study recommends using the sludge of sewage as a biological resource for conditioning of soil and contamination of both wheat and soil can also be avoided with the use of lower amount of sewage sludge.

\section{Authors' contributions}

Conceived and designed the experiments: ZI Khan \& K Ahmad, Performed the experiments: $\mathrm{F}$ Zameer, $\mathrm{M}$ Akhter \& $\mathrm{P}$ Akhtar, Analyzed the data: K Wajid, M Ghazzal \& A Ashfaq, Contributed reagents/ materials/ analysis tools: $\mathrm{H}$ Bahir N Mehmood \& M Nadeem, Wrote the paper: AI Batool, IS Malik \& M Munir.

\section{References}

1. Tsadilas CD, Matsui T, Barbayiannis N \& Dimoyiannis D (1995). Influence of sewage sludge application on soil properties and on the distribution and availability of heavy metal fractions. Commun Soil Sci Plant Anal 26: 2603-2619.

2. Khan ZI, Malik S, Ahmad K, Wajid K, Munir M, Ugulu I \& Dogan Y (2019a). Efficacy of transfer of heavy metals in wheat grown in municipal solid waste amended soil. Catrina IN PRESS

3. Khan ZI, Nisar A, Ugulu I, Ahmad K, Wajid K, Bashir $\mathrm{H} \&$ Dogan $\mathrm{Y}$ (2019). Determination of cadmium concentrations of vegetables grown in soil irrigated with wastewater: evaluation of health risk to the public. Egypt $J$ Bot in Press https://doi.org/10.21608/EJBO.2019.9 969.1296.

4. Poehlman JM \& Sleeper DA (1995). Breeding Field Crops. 4ed. Iowa State University Press, pp 259-262, 274 277.

5. Anonymous (2006). Govt. Pakistan, ministry of food, agriculture and livestock. Econ Wing, Islamabad, pp 18-19.

6. Khan MA, Shirazi MU, Mukhtiar A, Mumtaz S, Shereen A \& Ashraf MY (2006). Comparative performance of some wheat genotypes growing under saline water. Pak J Bot 38(5): 16331639.

7. Khan ZI, Iqbal S, Batool F, Ahmad K, Elshikh MS, Al Sahli A, et al. 2017. Evaluation of heavy metals uptake by wheat growing in sewage irrigated soil: Relationship with heavy metal in soil and wheat grains. Fresen Environ Bull 26(12A): 7838-7848.

8. Khan ZI, Safdar H, Ahmad K, Wajid $\mathrm{K}$, Bashir H, Ugulu I \& Dogan Y (2019c). Health risk assessment through determining bioaccumulation of iron in forages grown in soil irrigated with city effluent. Environ Sci Pollut Res 26(14): 14277-14286.

9. Khan ZI, Iqbal S, Ahmad K, Ashfaq A, Bashir H \& Dogan Y (2019d). Assessment of heavy metal content of wheat irrigated with wastewater in Sargodha, Pakistan: Implications for human health. Trace Elem Electroly 36(2): 82-92.

10. World Health Organization (1981). Environmental health criteria (No.16-19).

11. Khan ZI, Ahmad K, Safdar H, Ugulu I, Wajid K, Bashir $\mathrm{H}$ \& Dogan Y (2018). Manganese bioaccumulation and translocation of in forages grown in soil irrigated with city effluent: An evaluation on health risk. Res J Pharm Biol Chem Sci 9(5): 759-770. 
12. Chen YY, He YF, Luo YM, Yu YL, Lin Q \& Wong MH (2003). Physiological mechanism of plant roots exposed to cadmium. Chemosphere 50: 789-793.

13. Ahmad K, Nawaz K, Khan ZI, Nadeem M, Wajid K, Ashfaq A, et al (2018a). Effect of diverse regimes of irrigation on metals accumulation in wheat crop: An assessment - dire need of the day. Fresen Environ Bull 27(2): 846-855.

14. Ahmad K, Kokab R, Khan ZI, Ashfaq A, Bashir H, Mudasra M, et al (2018b) Assessment of heavy metals in wheat variety "Chagi-2"' under short-term wastewater irrigation. Biologia (Lahore, Pakistan) 64(1): 15-25.

15. Ahmad K, Ashfaq A, Khan ZI, Bashir H, Sohail M, Mehmood N \& Dogan Y (2018c). Metal accumulation in Raphanus sativus and Brassica rapa: An assessment of potential health risk for inhabitants in Punjab, Pakistan. Environ Sci Pollut Res 25(8): 1667616685.

16. Ghosh M \& Singh SP (2005). A review on phytoremediation of heavy metals and utilization of it's by products. Asian $J$ Energy Environ 6(4): 18.

17. Liu WH, Zhao JZ, Ouyang ZY, Soderlund L \& Liu GH (2005). Impacts of sewage irrigation on heavy metals distribution and contamination in Beijing, China. Environ Int 31: 805-812.

18. Sajjad K, Farooq R, Shahbaz S, Khan MA \& Sadique M (2009). Health risk assessment of heavy metals for population via consumption of vegetables. World Appl Sci J 6: 16021606.

19. Cui YJ, Zhu YG, Zhai RH, Chen DY, Huang YZ, Qui Y \& Liang JZ (2004). Transfer of metals from near a smelter in Nanning, China. Environ Int 30: 785-791.
20. USEPA (United State Environmental Protection Agency). 2002. Region 9, Preliminary Remediation Goals.

21. Al-Hwaiti $\mathrm{M} \&$ Al-Khashman O (2015). Health risk assessment of heavy metals contamination in tomato and green pepper plants grown in soils amended with phosphogypsum waste materials. Environ Geochem Health 37(2): 287-304.

22. Ozyazici M (2013). Effects of sewage sludge on the yield of plants in the rotation system of wheat-white head cabbage-tomato. Eurasian J Soil Sci 2: 35-44.

23. $\mathrm{Yu} \mathrm{X}$, Wang $\mathrm{Z}$, Lynn A, Cai J, Huangfu Y, Geng Y, Tang J \& Zeng $X$ (2016). Heavy metals in wheat grown in sewage irrigation: A distribution and prediction model. Polish J Environ Study 25(1): 413418.

24. Stefanovic VC, Filipovic NK \& Jovanovich BM (2008). Undesirable metals content in wheat of different wheat varieties. Apteff 39: 69.

25. Ran J, Wang D, Wang C, Zhang G \& Zhang H (2016). Heavy metal contents, distribution, and prediction in a regional soil-wheat system. Sci Total Environ 544: 422-431.

26. Antolin MC, Pascal I, Garcia C, Polo A \& Sanchez-Diaz M (2005). Growth, yield and solute content of barley in soils treated with sewage sludge under semiarid Mediterranean conditions. Field Crops Res 94: 224-237.

27. Outridge PM \& Noller BN (1991). Accumulation of toxic trace elements by freshwater vascular plants. In Reviews of Environmental Contamination and Toxicology. Springer, New York, NY, pp 1-63.

28. Ahmad K, Khan ZI, Yasmin S, Ashraf M \& Ishfaq A (2014). Accumulation of metals and metalloids in turnip (Brassica rapa L.) irrigated with domestic wastewater in the peri-urban areas of Khushab City, Pakistan. Pak J Bot 42(2): 511-514. 
29. Jayakumar K, Vijayarengan $P$, Vijayaragavan M, Rajasekaran S \& Sumathi K (2006). Toxicological aspects of cobalt induced growth and morphological changes in Helianthus annuus (L.). Plant Arch 6: 829-830.

30. Hassan N, Mahmood Q, Waseem A, Irshad M \& Pervez A (2011). Assessment of heavy metals in wheat plants irrigated with contaminated wastewater. Polish $J$ Environ Stud 22(1): 115-123.

31. Bakkaus E, Gouge B, Gallien JP, Khodja H, Carrot H, Morel JL \& Collins R (2005). Concentration and distribution of cobalt in higher plants: the use of micro-PIXE spectroscopy. Nucl Instr Meth B 231: 350-356.

32. Palit S, Sharma A \& Talukder G (1994) Effects of cobalt on plants. Bot Rev., 60(2): 149-81.

33. McGrath SP, Chang AC, Page AL \& Witter E (1994). Land application of sewage sludges. Scientific perspectives of heavy metal loading limits in Europe and United States. Environ Rev 2: 108-118.

34. McLaughlin MJ, Parker DR \& Clarke JM (1996) Metals and micronutrientsfood safety issues. Field Crops Res 60: 143-163.

35. Chaudri AM, Mcgrath SP \& Giller KE (1992). Survival of indigenous population of rhizobium Ieguminosarum Biovar Trifolii in soil spiked with $\mathrm{Cd}, \mathrm{Zn}, \mathrm{Cu}$ and Ni Salts. Soil Biol Biochem 24: 625.

36. Chaudri AM, Allain CMG, Badawy SH, Adams ML, McGrath SP \& Chambers BJ (2001). Cadmium content of wheat grain from a longterm field experiment with sewage sludge. J Environ Qual 30: 15751580 .

37. Kaneta M, Hikici $H$, Endo $S$ \& Sugiyama N (1986). Chemical form of cadmium (and other heavy metal) in rice and wheat plant. Environ Health Perspectives 65: 33-37.
38. FAO/WHO (2001). Codex Alimentarius Commission. Food additive and contaminants. Joint FAO/ WHOFood Standards Programme, ALINORM 01/ 12A, pp 1-289.

39. Khan MJ, Jan MT \& Khan K (2013). Effects of organic and inorganic amendments on the heavy metal content of soil and wheat crop irrigated with wastewater. Sarhad J Agric 29(1): 49-57.

40. Morrissey J \& Guerinot ML (2009). Iron uptake and transport in plants: the good, the bad, and the ionone. Chem Rev 109(10): 4553-4567.

41. Herren T \& Feller U (1997). Influence of increased zinc levels on phloem transport in wheat shoots. $J$ Plant Physiol 150: 228-231.

42. Hart JJ, Welch RM, Norvell WA, Sullivan LA \& Kochian LV (1998). Characterization of cadmium binding, uptake and translocation in intact seedlings of bread and durum wheat cultivars. Plant Physiol 116: 14131420.

43. Ashfaq A, Khan ZI, Bibi Z, Ahmad K, Ashraf M, Mustafa I, Akram NA, Perveen R \& Yasmeen S (2015) Heavy metal uptake by Cucurbita maxima grown in soil contaminated with sewage water and its human health implications in peri-urban areas of Sargodha city. Pak J Zoo 47(4): 1051-1058.

44. Bashir F, Kashmiri MA, Shafiq $T$ \& Tariq M (2009). Heavy metals uptake by vegetables growing in sewage irrigated soil: relationship with heavy metal fractionation in soil. Chem Spec Bioavail 21(4): 199-209.

45. Puschenreiter M, Horak O, Friesl W \& Hartl W (2005). Low-cost agricultural measures to reduce heavy metal transfer into the food chain - a review. Plant Soil Environ 51(1): 1-11.

46. Wang $H$, Zhong G, Shi G \& Pan F (2011) Toxicity of $\mathrm{Cu}, \mathrm{Pb}$, and $\mathrm{Zn}$ on Seed germination and Young Seedlings of Wheat (Triticum 
aestivum L.).The Project was supported by Fundamental Research Funds for the Central Universities, 5006-0402.

47. Iqbal $\mathrm{HH}$, Taseer $\mathrm{R}$, Anwar $\mathrm{S}$, Mumtaz M, Qadir A \& Shahid N (2016). Human health risk assessment: heavy metal contamination of vegetables in Bahawalpur, Pakistan. Bullet Environ Stud 1(1): 10-17.

48. Bose S \& Bhattacharyya AK (2008). Heavy metal accumulation in wheat plant grown in soil amended with industrial sludge. Chemosphere 70 : 1264-1272.

49. Rabee AM, Al-Fatlawy YF, Abdown AN \& Nameer M (2011). Using pollution load index (PLI) and geoaccumulation index (I-geo) for the assessment of heavy metals pollution in Tigris River sediment in Baghdad region. J Al-Nahrain University 14: 108-114.

50. Ghrefat H, Abu-Rukah Y \& Rosen MA (2011) Application of geoaccumulation index and enrichment factor for assessing metal contamination in the sediments of Kafrain Dam Jordan. Environ Monit Assess 178(1-4): 95-109.

51. McCave IN (1984). Size spectra and aggregation of suspended particles in the deep ocean. Deep Sea Res 31: 329352.

52. Horowitz AJ \& Elrick KA (1987). The relation of stream sediment surface area, grain size and composition to trace element chemistry. Appl Geochem 2: 437-451.

53. Ra K, Kim JK, Hong SH, Yim UH, Shim WJ, Lee SE, Kim YO, Lim J, Kim ES \& Kim KT (2014). Assessment of pollution and ecological risk of heavy metals in the surface sediments of Ulsan Bay, Korea. Ocean Sci J 49(3): 279-289.

54. Gupta S, Jena V, Jena S, Davi N, Mati N, Radojevi D \& Solanki JS (2013). Assessment of heavy metal contents of green leafy vegetables. Croatia $J$ Food Sci Technol 5(2): 53-60.

55. Huang M, Zhou S, Sun B \& Zhao Q (2008). Heavy metals in wheat grain: assessment of potential health risk for inhabitants in Kunshan, China. Sci Total Environ 405: 54-61.

56. Khan S, Cao Q, Zheng YM, Huang YZ \& Zhu YG (2008). Health risks of heavy metals in contaminated soils and food crops irrigated with wastewater in Beijing, China. Environ Pollut 152(3): 686-692.

57. Karak T \& Bhattacharyya P (2010). Heavy metal accumulation in soil amended with roadside pond sediment and uptake by winter wheat (Triticum aestivum L. cv. pbw 343). The Scientific World J 10: 2314-2329.

58. USEPA (United State Environmental Protection Agency). 2010. Integrated Risk Information System. 